\title{
Evaluation of induced pitting damage of late season cherries 'Regina' and 'Sweetheart' using an impact energy method
}

Maria E. Gonzalez ${ }^{1 *}$, Natalia F. Valderrama ${ }^{1}$, Richard M. Bastias ${ }^{2}$, Raúl Baeza ${ }^{2}$, Ana M. Valdebenito ${ }^{1}$, Gonzalo Diaz ${ }^{1}$, and Kenneth A. Shackel ${ }^{3}$

\section{ABSTRACT}

Late season cherry (Prunus avium [L.] L.) cultivars have turned of important relevance in production systems of the south of Chile with a continuous increase in exports. Cherries reach final markets after long distance ocean shipping and pitting damage continues to be the main postharvest detrimental quality loss during this period. Different factors affect pitting expression responses during harvest and postharvest fruit management. The aim of this study was to determine the influence of postharvest factors in pitting development of two late cherry 'Regina' and 'Sweetheart' using an impact energy method. Maturity stage (red and dark red), impact energy (0.00342 and $0.0107 \mathrm{~J})$ and storage time $(0,7,14,21,28 \mathrm{~d})$ were evaluated. Fruit composition (soluble solids, $\mathrm{pH}$, and titratable acidity), weight loss (\%) and firmness were measured. Induced pitting was determined after allocating a known impact energy level and obtaining an imprint of the damaged area. Pit diameter, depth and volume were determined by light microscopy techniques and image analysis. Pitting damage that occurred naturally on fruit picked at commercial maturity stage was determined at harvest and during cold storage. The induced pitting device allowed for the application of a mechanical injury of known impact energy, useful to determine pitting susceptibility differences among cultivars. The coefficient of variation of the method was 0.18 for pit diameter, 0.37 for pit depth and 0.6 for pit volume, indicating repeatability of results independent of the impact energy applied or the variety studied. 'Sweetheart' showed higher incidence of induced pitting during storage, with an average 2.8 pit volume increase compared to a 2.2 increase in 'Regina' during the same period. Naturally occurring damage of commercial fruit verified results obtained with the induced pitting device, with 'Sweetheart' more susceptible than 'Regina' $(\mathrm{P}<0.05)$.

Key words: Fruit surface depression, imprint, postharvest, Prunus avium.

${ }^{1}$ Universidad de Concepción, Facultad de Ingeniería Agrícola, Casilla 537, Chillán, Chile. *Corresponding author (mariaegonzalez@udec.cl). ${ }^{2}$ Universidad de Concepción, Facultad de Agronomía, Casilla 537, Chillán, Chile.

${ }^{3}$ University of California, Department of Plant Sciences, One Shields Avenue, Davis, California, USA.

Received: 1 June 2016.

Accepted: 21 September 2016.

doi:10.4067/S0718-58392016000400011

\section{INTRODUCTION}

Late season cherry (Prunus avium [L.] L.) cultivars are an important commercial strategy for growers in many parts of the world. In Chile, late season cultivars allow to extend the short harvest period and reach Asian markets that highly appreciate this fruit in their festive periods (industry communication). Producers in the US Pacific Northwest, grow late-maturing cultivars to avoid low returns associated with fruit harvested during the peak midseason when cherry supplies are overly abundant (Einhorn et al., 2013). On the other hand, long distance shipping to export markets implies cherry quality deterioration that includes flavor loss, off-flavor development, skin darkening, pedicel browning, decay and cherry pitting (Wang et al., 2015).

Pitting damage can occur during harvest and postharvest handling and becomes noticeable once in cold storage (Crisosto et al., 1993). Surface pitting consists in the development of one or more irregular and hardened depressions, which occur predominantly in the upper part of the pedicel area. Wade and Bain (1980) mention surface pits to occur when cells in the hypodermis and first layer of mesocarp collapse. Literature defines two different types of pitting: the damage that occurs when enough pressure is applied gradually (compression), and the one that occurs instantaneously (impact) (Porritt et al., 1971; Facteau and Rowe, 1979).

Studies conducted by Lidster et al. (1980) showed that the highest incidence of pitting was obtained in phase III of fruit growth from the end of pit hardening to harvest, period that is characterized by an increase in cell expansion. Recent studies in late season 'Sweetheart' and 'Lapins' indicated that low concentration applications of gibberellic acid $\left(\mathrm{GA}_{3}\right)$ (between 10 and $25 \mathrm{mg} \mathrm{L}^{-1}$ ) at the end of pit hardening consistently improved fruit firmness (in a range of $10 \%$ to $43 \%$ ) and reduced surface pitting disorder after 4 wk cold storage (Einhorn et al., 2013). The authors suggest as well that unidentified endogenous factors that regulate fruit firmness are inducible by $\mathrm{GA}_{3}$ and responsible for improved resistance to pitting.

In general, fruit bruise responses can be affected by other factors besides the injury itself applied with postharvest practices playing an important role. Fruit temperature management before and after the impact may modulate tissue recovery and expressed severity (Lidster and Tung, 1980; Toivonen et al., 2007). An increased respiratory rate increased water loss and temperature in the fruit, which was directly proportional to the development of pitting (Crisosto et al., 1993; Toivonen et al., 2004). The addition of calcium chloride $\left(\mathrm{CaCl}_{2}\right)$ to hydro-cooling water of late 'Lapins' and 'Sweetheart', increased tissue Ca content and enhanced 
quality after cold storage due to reductions in respiration rate, ascorbic acid degradation and membrane lipid peroxidation, accompanied by an increase in fruit firmness and pitting resistance (Wang et al., 2014).

In addition, studies report pitting sensitivity dependence on cultivar (Kappel et al., 2006; Candan et al., 2014) and maturity stage (Kupferman and Sanderson, 2005). Cherry commercial maturity is mainly based on consumer acceptance of color, percent of soluble solids (Crisosto et al., 2003), and firmness (Clayton et al., 2006; Hampson et al., 2014). According to Zoffoli (2012), cherries in an advanced maturity stage (dark mahogany skin color), presented less firmness and incidence of pitting increased $40 \%$ in storage compared to less mature cherries (mahogany skin color). The sensitivity of cherries to pitting has been related to fruit firmness (Toivonen et al., 2004) since this parameter determines tissue responses to mechanical forces (Mitcham et al., 1998). Brüggenwirth and Knoche (2016a) quantified cherry skin mechanical properties, and observed a decrease in skin stiffness indicated by a decrease in elastic modulus when enzymatic degradation of the cell wall during ripening, relaxation of cell walls on decreasing turgor or exposure to high temperatures occurred. Salato et al. (2013) evaluated the changes in cell wall composition of two cultivars of contrasting firmness, 'Sweetheart' and 'Newstar', a firm and soft cultivar respectively, indicating a higher content of cell wall material, less branching of tightly bound pectins in the cell wall and less content of neutral sugar-rich pectin side chains in the firmer cultivar.

Few studies have compared surface pitting responses of late season cherry cultivars, therefore the aim was to evaluate the influence of postharvest factors: maturity stage, impact energy level and storage time on the development of pitting in late season 'Regina' and 'Sweetheart' using a novel impact energy device.

\section{MATERIALS AND METHODS}

\section{Fruit materials and storage conditions}

Fruit were harvested from a commercial orchard of 'Regina' and 'Sweetheart' grafted on 'Mazzard F12' with trees trained to a central-leader. The orchard was located in the commune of Perquenco ( $38^{\circ} 24^{\prime}$ S, $72^{\circ} 22^{\prime}$ 'W; 278 m a.s.l.), La Araucanía Region, Chile. The climate corresponding to the area is humid temperate, with an average annual temperature of $12^{\circ} \mathrm{C}$, an average temperature of $8^{\circ} \mathrm{C}$ in the coldest month and an average of $15^{\circ} \mathrm{C}$ in the warmest month. The average rainfall is $1500 \mathrm{~mm}$ with a relatively dry period of 3-mo during summer. Soil classification corresponds to Andisols.

Cherries were harvested between 08:00 and 10:00 h, placed in containers and transported to the laboratory. Fruit were inspected and classified according to maturity stage in two levels: red and dark red, using the commercial scale for maturity stages (light red, red, dark red, mahogany, and dark mahogany). Only sound fruit were used for induced pitting studies. Fruit diameter was in the range of 24-26 mm. After segregation and treatments were applied, fruit were placed in polystyrene speedling trays and cold stored at $1 \pm 2{ }^{\circ} \mathrm{C}$ and $90-95 \%$ RH.

\section{Fruit quality parameters}

Fruit composition was determined by measuring soluble solids content with a handheld refractometer $\left(0-32^{\circ}\right.$ Brix, ATC-1E, Atago, Tokyo, Japan), titratable acidity was expressed as malic acid (meq $\mathrm{kg}^{-1}$ ) and $\mathrm{pH}$ determined with a digital pH meter (HI 8521, Hanna Instruments, Woonsocket, Rhode Island, USA).

Fruit firmness was defined with a compression test carried with a universal testing machine (Model 3345, InstronCorp, Canton, Massachusetts, USA) and a $35 \mathrm{~mm}$ head diameter probe was used at crosshead speed of $6 \mathrm{~mm}$ $\min ^{-1}$. The force-deformation curve obtained was used to determine the initial slope (at $2 \mathrm{~mm}$ deformation, $\mathrm{N} \mathrm{mm}^{-1}$ ).

Weight loss during storage was evaluated using the following formula:

$$
\text { Weight loss }(\%)=\left(\frac{W i-W f}{W i}\right) \times 100
$$

where, $W i$ is initial fruit weight $(\mathrm{g})$ and $W f$ is final fruit weight after storage $(\mathrm{g})$.

\section{Pitting induction}

Pitting damage was induced with a pendulum device (Figure 1). A single impact was applied on the upper pedicelar area of the fruit. Fruit temperature was $20^{\circ} \mathrm{C}$ when treatment was applied. Two impact levels were evaluated according to the pendulum trajectory, $45^{\circ}$ and $90^{\circ}$, equivalent to 0.00342 and $0.0107 \mathrm{~J}$ impact energies, respectively. The applied impact energy was calculated by dividing mechanical energy into kinetic and potential energy at the initial and end point position of the pendulum. At the initial point (A),

Figure 1. Mechanical device used to induce pitting. Impact levels 0.00342 and $0.0107 \mathrm{~J}$ were calculated as the impact energies on the fruit when the pendulum moved from an angle of $45^{\circ}$ and $90^{\circ}$ respectively with regard to the vertical position of the pendulum.

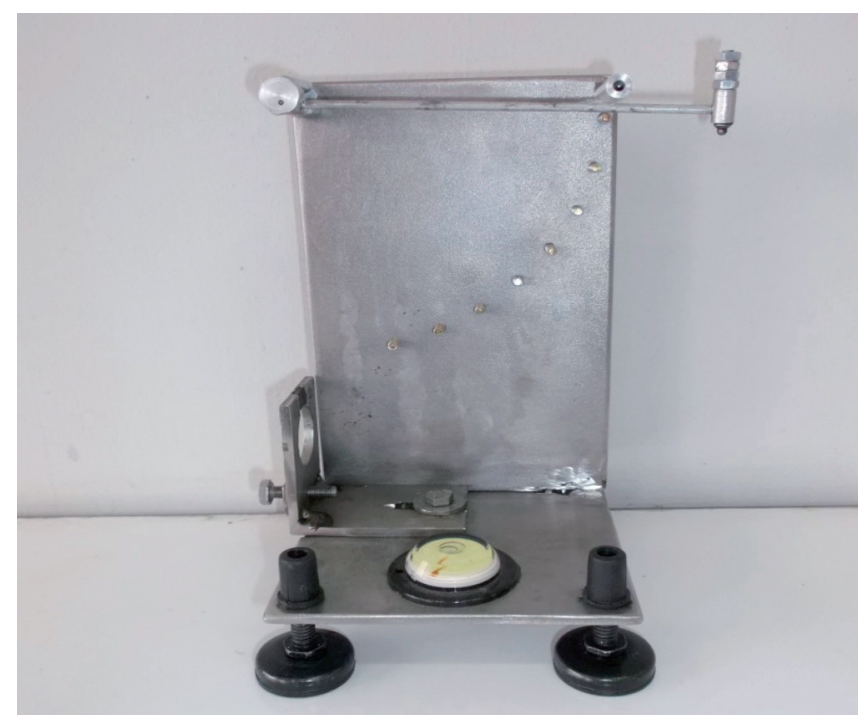


the velocity is zero and at the end point (B) height is zero. It was determined that the system did no work $(\mathrm{W}=0)$ by applying lubricants to reduce the friction of the pendulum with its axis. The mass of the pendulum was $8.38 \times 10^{-4}$ $\mathrm{kg}$. Equation [2] was used to obtain the velocity of the pendulum. Time of trajectory was obtained by recording the pendulum movement from point $\mathrm{A}$ to $\mathrm{B}$.

$$
\begin{gathered}
P E_{A}+K E_{A}+W=P E_{B}+K E_{B} \\
\left(m_{A} g_{A} h_{A}\right)+\left(1 / 2 m_{A} v_{A}^{2}\right)+W=\left(m_{B} g_{B} h_{B}\right)+\left(1 / 2 m_{B} v_{B}^{2}\right) \\
a=v\left(m s^{-1}\right) t^{-1}(s) \\
F=m(k g) a\left(m s^{-2}\right) \\
E=F(N) h_{A}(m)
\end{gathered}
$$

where, $P E$ is potential energy; $K E$ is kinetic energy; $W$ is work (Equation [2]); $m$ is pendulum mass $(\mathrm{kg}) ; g$ is gravity acceleration $\left(\mathrm{m} \mathrm{s}^{-2}\right) ; v$ is velocity $\left(\mathrm{m} \mathrm{s}^{-1}\right) ; h$ is height (m) (Equation [3]); $a$ is acceleration $\left(\mathrm{m} \mathrm{s}^{-2}\right) ; t$ is time (s) (Equation [4]); $F$ is force (N) (Equation [5]) and $E$ is impact energy (J) (Equation [6]).

\section{Pitting damage}

Induced pitting damage was evaluated by non-destructively forming molds of the damaged area (Kappel and Toivonen, 2005) using chromatic alginate (Gel-plus, Egeo, Buenos Aires, Argentina). A hand cross section of the mold was made through the central zone, and the diameter and depth $(\mathrm{mm})$ of the damage were measured using an optical microscope (Axiostar Plus, Carl Zeiss, Oberkochen, Germany) with a digital camera (PowerShot A620, Canon, Tokyo, Japan) coupled to it. Pit volume $\left(\mathrm{mm}^{3}\right)$ was determined using the following formula:

$$
V=\frac{\pi \times r^{2} \times h}{3}
$$

where, $V$ is volume $\left(\mathrm{mm}^{3}\right), r$ is radius $(\mathrm{mm})$, and $h$ is height $(\mathrm{mm})$.

Pitting damage that occurred naturally on commercial mature fruit was evaluated as described by Torrealba (2005), by inspecting occurring pits on commercial fruit at harvest and during storage. Four categories for visible pitting damage were used: Sound, which corresponds to fruit with no damage; Light damage, $\leq 3$ depressions with diameter $<1 \mathrm{~mm}$; Moderate damage, $\leq 2$ depressions with diameter $<3 \mathrm{~mm}$; Severe damage: depressions greater than those previously described.

\section{Experimental design and statistical analysis}

A factorial experimental design was used with maturity (red and dark red stage), impact energy (0.00342 and $0.0107 \mathrm{~J})$ and storage time evaluated $(0,7,14,21$, and $28 \mathrm{~d})$. Fruit physical-chemical determinations were conducted with three replicates of 10 fruits each, while weight loss (\%), firmness $\left(\mathrm{N} \mathrm{mm}^{-1}\right)$ and induced pitting were conducted with 15 replicates (with experimental unit a fruit). ANOVA was used to determine significant differences between treatments and Tukey test used to determine differences between means at $95 \%$ significance level. The coefficient of variation for pit diameter, depth and volume were analyzed. Pearson correlation analysis was conducted to analyze the relationship between pit volume and fruit firmness $(\mathrm{P} \leq 0.05)$.

Pitting damage occurring naturally on commercial mature fruit was evaluated with a simple frequency analysis of data obtained at three different time points $(0$, 14 , and 28 d) with 150 replicates (fruits) per time point and maturity stage. Significant differences among cultivars were obtained by analysis of differences in proportions within categories $(\mathrm{P} \leq 0.05)$.

The statistical software used was InfoStat version 2012 (National University of Córdoba, Córdoba, Argentina).

\section{RESULTS}

\section{Fruit quality parameters}

Both cultivars showed higher soluble solids content for dark red compared to red stage fruit $(\mathrm{P} \leq 0.05)$, impact level showed no effect on this parameter and it did not present significant variations during storage (Tables 1 and 2). Both cultivars increased $\mathrm{pH}$ with time. 'Regina' indicated higher $\mathrm{pH}$ values on days 21 and 28 than at initial storage time $(\mathrm{P} \leq 0.05)$ and this parameter differed between maturity stages on day 7 and 14. 'Sweetheart' showed higher $\mathrm{pH}$ values on day 28 and maturity stage values only differed on this day. The level of impact

\begin{tabular}{|c|c|c|c|c|c|c|c|c|c|c|c|}
\hline & \multirow{3}{*}{$\begin{array}{l}\text { Maturity } \\
\text { stage }\end{array}$} & \multicolumn{10}{|c|}{ Days } \\
\hline & & \multicolumn{2}{|c|}{0} & \multicolumn{2}{|c|}{7} & \multicolumn{2}{|c|}{14} & \multicolumn{2}{|c|}{21} & \multicolumn{2}{|c|}{28} \\
\hline & & $45^{\circ}$ & $90^{\circ}$ & $45^{\circ}$ & $90^{\circ}$ & $45^{\circ}$ & $90^{\circ}$ & $45^{\circ}$ & $90^{\circ}$ & $45^{\circ}$ & $90^{\circ}$ \\
\hline \multirow[t]{2}{*}{ Soluble solids, ${ }^{\circ}$ Brix } & $\mathrm{R}$ & $19.8 \mathrm{Bb}$ & $19.8 \mathrm{Bb}$ & $18.7 \mathrm{Bb}$ & 19.3Bb & 19.2Bb & $19.7 \mathrm{Bb}$ & $19.5 \mathrm{Bb}$ & $20.2 \mathrm{Bb}$ & $20.1 \mathrm{Bb}$ & $21 \mathrm{Ab}$ \\
\hline & DR & $21.6 \mathrm{Aa}$ & $21.6 \mathrm{Aa}$ & $20.2 \mathrm{Aa}$ & $20.6 \mathrm{Aa}$ & $21.1 \mathrm{Aa}$ & $20.9 \mathrm{Aa}$ & $20.8 \mathrm{Aa}$ & $21.1 \mathrm{Aa}$ & $20.9 \mathrm{Aa}$ & $19.8 \mathrm{Ba}$ \\
\hline \multirow[t]{2}{*}{$\mathrm{pH}$} & $\mathrm{R}$ & $3.9 \mathrm{Ac}$ & 3.9Ac & $4.0 \mathrm{Ac}$ & $4.1 \mathrm{Ac}$ & $4.0 \mathrm{Bc}$ & $4.0 \mathrm{Bc}$ & $4.2 \mathrm{Ab}$ & $4.2 \mathrm{Ab}$ & $4.5 \mathrm{Aa}$ & $4.5 \mathrm{Aa}$ \\
\hline & DR & $3.9 \mathrm{Ac}$ & 3.9Ac & $3.9 \mathrm{Bc}$ & $3.9 \mathrm{Bc}$ & $4.1 \mathrm{Ac}$ & 4.1Ac & $4.3 \mathrm{Ab}$ & $4.2 \mathrm{Ab}$ & $4.5 \mathrm{Aa}$ & 4.4Aa \\
\hline \multirow[t]{2}{*}{ Titratable acidity, meq kg-1 } & $\mathrm{R}$ & $90.5 \mathrm{Aa}$ & 89.6Aa & $91.2 \mathrm{Aa}$ & 90.9Aa & $85.2 \mathrm{Ab}$ & $84.6 \mathrm{Ab}$ & 81.6Ac & 77.2Ac & $77.5 \mathrm{Ac}$ & 77.6Ac \\
\hline & DR & $87.8 \mathrm{Ba}$ & $84.7 \mathrm{Ba}$ & $85.0 \mathrm{Ba}$ & $89.4 \mathrm{Ba}$ & $82.1 \mathrm{Bb}$ & $84.5 \mathrm{Bb}$ & $77.9 \mathrm{Bc}$ & $76.4 \mathrm{Bc}$ & $71.0 \mathrm{Bd}$ & 71.9Bd \\
\hline
\end{tabular}
showed nonsignificant effects on this parameter (Tables 1 and 2). Titratable acidity (meq $\mathrm{kg}^{-1}$ ) decreased in 'Regina' from day 14 onwards $(\mathrm{P} \leq 0.05)$ (Table 1$)$. The same was observed in 'Sweetheart' as of day 21 (Table 2). Dark

Table 1. Physicochemical parameters for 'Regina' according to maturity stage, impact level and storage time.

DR: Dark red, R: red; $45^{\circ}: 0.00342 \mathrm{~J}, 90^{\circ}: 0.0107 \mathrm{~J}$.

Different capital letters indicate significant differences between rows and different lower-case letters indicate significant differences between columns according to Tukey's test $(\mathrm{P} \leq 0.05)$ considering the significance of main effects and interactions. 
Table 2. Physicochemical parameters for 'Sweetheart' according to maturity stage, impact level and storage time.

\begin{tabular}{|c|c|c|c|c|c|c|c|c|c|c|c|}
\hline & \multirow{3}{*}{$\begin{array}{l}\text { Maturity } \\
\text { stage }\end{array}$} & \multicolumn{10}{|c|}{ Days } \\
\hline & & \multicolumn{2}{|c|}{0} & \multicolumn{2}{|c|}{7} & \multicolumn{2}{|c|}{14} & \multicolumn{2}{|c|}{21} & \multicolumn{2}{|c|}{28} \\
\hline & & $45^{\circ}$ & $90^{\circ}$ & $45^{\circ}$ & $90^{\circ}$ & $45^{\circ}$ & $90^{\circ}$ & $45^{\circ}$ & $90^{\circ}$ & $45^{\circ}$ & $90^{\circ}$ \\
\hline \multirow[t]{2}{*}{ Soluble solids, ${ }^{\circ}$ Brix } & $\mathrm{R}$ & $20.7 \mathrm{Bb}$ & $20.7 \mathrm{Bb}$ & $20.3 \mathrm{Bb}$ & $20.1 \mathrm{Bb}$ & $20.7 \mathrm{Bb}$ & $20.1 \mathrm{Bb}$ & $21.3 \mathrm{Bb}$ & $21.2 \mathrm{Bb}$ & $20.7 \mathrm{Bb}$ & $20.7 \mathrm{Bb}$ \\
\hline & DR & $22.7 \mathrm{Aa}$ & $22.7 \mathrm{Aa}$ & 21.9Aa & $22.7 \mathrm{Aa}$ & $22.7 \mathrm{Aa}$ & $23 \mathrm{Aa}$ & $23.3 \mathrm{Aa}$ & $22.3 \mathrm{Aa}$ & $23 \mathrm{Aa}$ & $22.5 \mathrm{Aa}$ \\
\hline \multirow[t]{2}{*}{$\mathrm{pH}$} & $\mathrm{R}$ & $3.8 \mathrm{Ab}$ & $3.8 \mathrm{Ab}$ & $3.8 \mathrm{Ab}$ & $3.8 \mathrm{Ab}$ & $3.8 \mathrm{Ab}$ & $3.9 \mathrm{Ab}$ & 3.9Ab & $4.0 \mathrm{Ab}$ & $4.4 \mathrm{Ba}$ & $4.2 \mathrm{Ba}$ \\
\hline & DR & $3.8 \mathrm{Ab}$ & $3.8 \mathrm{Ab}$ & $3.8 \mathrm{Ab}$ & $3.9 \mathrm{Ab}$ & $4.0 \mathrm{Ab}$ & $3.9 \mathrm{Ab}$ & $4.0 \mathrm{Ab}$ & $4.1 \mathrm{Ab}$ & 4.7Aa & $4.6 \mathrm{Aa}$ \\
\hline \multirow[t]{2}{*}{ Titratable acidity, meq $\mathrm{kg}^{-1}$} & $\mathrm{R}$ & 117.0Aa & $114.4 \mathrm{Aa}$ & $116.5 \mathrm{Aa}$ & $113.8 \mathrm{Aa}$ & 114.9Aa & $114 \mathrm{Aa}$ & $108.0 \mathrm{Ab}$ & $106.0 \mathrm{Ab}$ & $109.3 \mathrm{Ab}$ & $108.6 \mathrm{Ab}$ \\
\hline & DR & $111.1 \mathrm{Ba}$ & $110.1 \mathrm{Ba}$ & $111.4 \mathrm{Aa}$ & $109.8 \mathrm{Ba}$ & 106.3Ba & $107 \mathrm{Ba}$ & $98.9 \mathrm{Bb}$ & $97.3 \mathrm{Bb}$ & $100.0 \mathrm{Bb}$ & $99.3 \mathrm{Bb}$ \\
\hline
\end{tabular}

DR: Dark red, R: red, $45^{\circ}: 0.00342 \mathrm{~J}, 90^{\circ}: 0.0107 \mathrm{~J}, \mathrm{~nm}$ : parameter not measured at this storage time.

Different capital letters indicate significant differences between rows and different lower-case letters indicate significant differences between columns according to Tukey's test $(\mathrm{P} \leq 0.05)$ considering the significance of main effects and interactions.

red fruit had lower titratable acidity than red fruit in both cultivars. The level of impact showed nonsignificant effect on this parameter.

Fruit firmness in 'Regina' and 'Sweetheart' was affected by storage time and maturity stage. Firmness decreased during storage and less deformation capacity was observed in red than dark red fruit (Figure 2). There was no impact effect on fruit firmness.

Weight loss levels increased as storage time passed for both cultivars. No differences were observed between levels of impact for either cultivar. Maturity stage did not have an effect in 'Regina', while weight loss was higher for dark red than for red fruit in 'Sweetheart' (Figure 3).

\section{Pitting damage}

The imprint technique used for induced pitting did not

Figure 2. Fruit firmness average for 'Regina' (A) and 'Sweetheart' (B) cherries during storage.
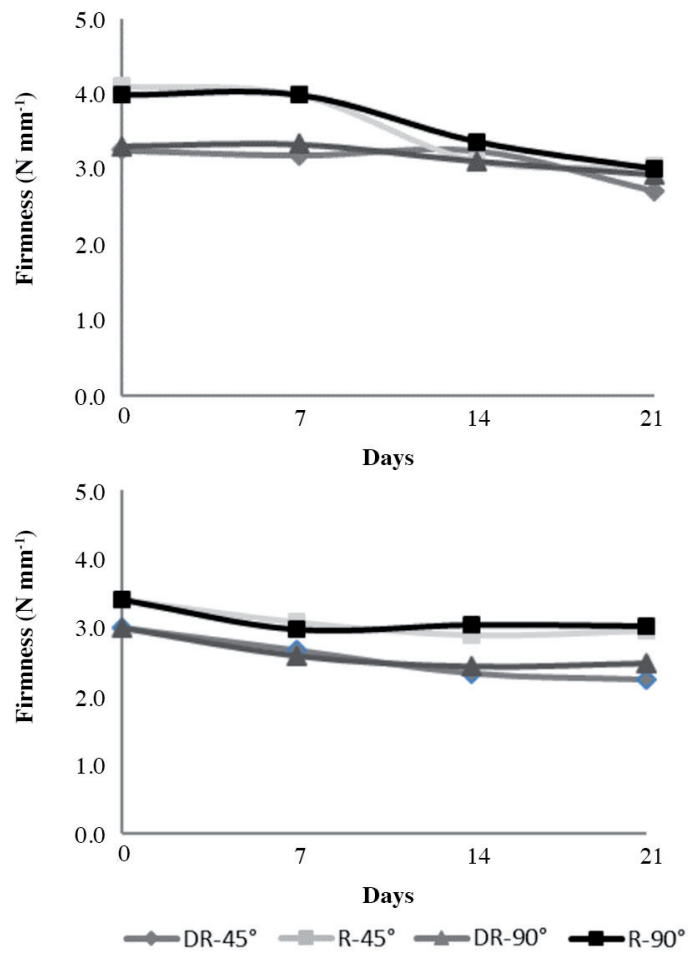

DR: Dark red, R: red, $45^{\circ}: 0.00342 \mathrm{~J}, 90^{\circ}: 0.0107 \mathrm{~J}$.
Figure 3. Weight loss average for 'Regina' (A) and 'Sweetheart' (B) cherries during storage.
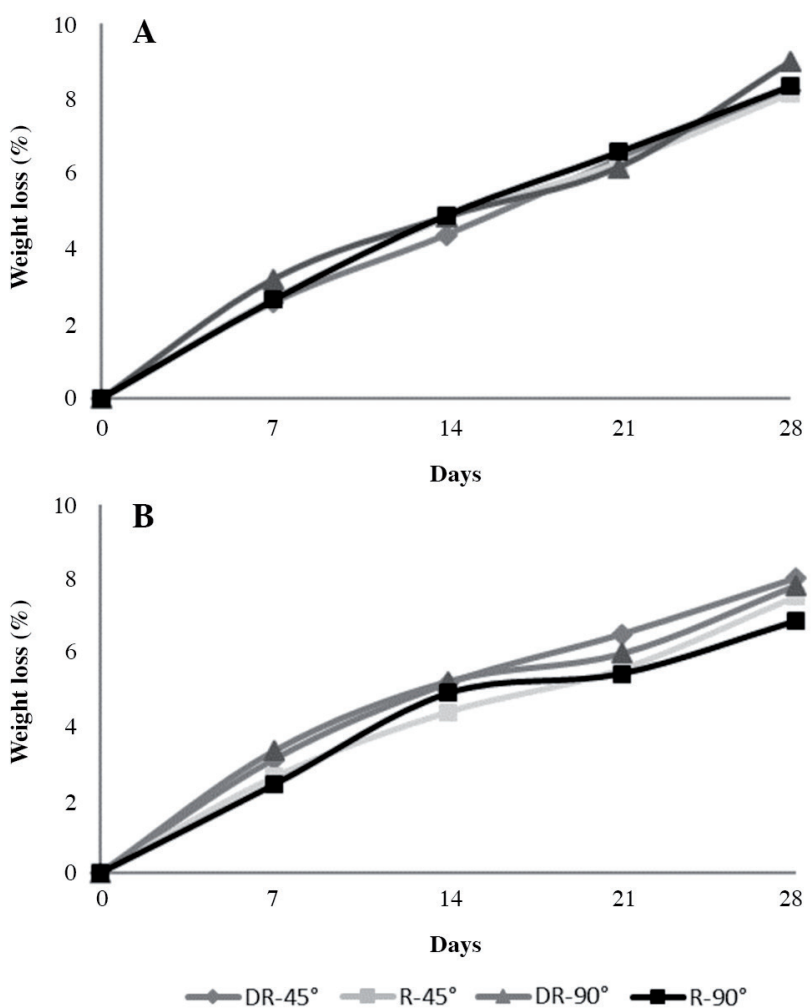

DR: Dark red, R: red, 45: 0.00342 J, $90^{\circ}: 0.0107$ J.

determine surface pitting damage on day 0 therefor pit parameters were analyzed after $1 \mathrm{wk}$ storage. Pit diameter indicated in 'Regina' interaction between time and impact energy, with no effect of maturity stage. On days 14 and 21 , higher impact energy showed greater pit diameter. On average during storage time a 1.1 and 1.4 fold in diameter was observed at the low and high impact energy levels applied. In 'Sweetheart', there was no effect of maturity stage on pit diameter and impact energy treatments differed only on day 14 and 21 for red fruit. There was a 1.1 and 1.3 fold in diameter at the low and high impact energy levels respectively over time (Figure 4).

Pit depth increased during storage in both cultivars (Figure 5). In 'Regina' pit depth evolved between day 7 and 
Figure 4. Development of induced pitting average diameter for 'Regina' (A) and 'Sweetheart' (B) cherries during storage.
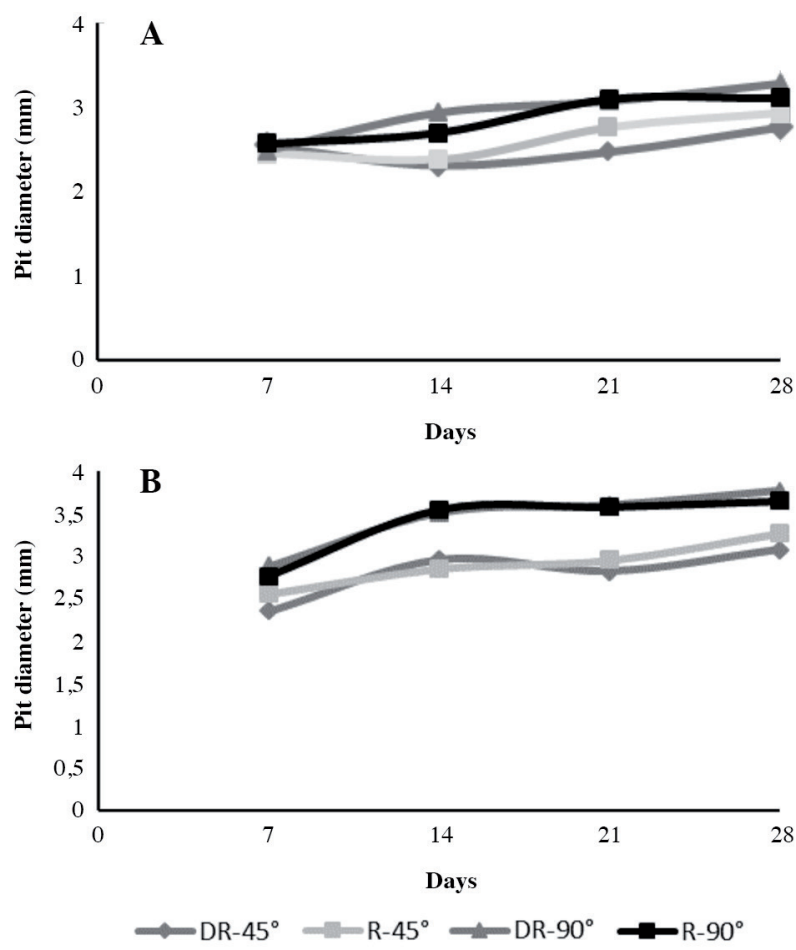

DR: Dark red, R: red, 45: 0.00342 J, $90^{\circ}: 0.0107 \mathrm{~J}$.

$\mathrm{CV}$ 'Regina' $45^{\circ}=0.18 ; \mathrm{CV}$ 'Regina' $90^{\circ}=0.19$

$\mathrm{CV}$ 'Sweetheart' $45^{\circ}=0.17 ; \mathrm{CV}$ 'Sweetheart' $90^{\circ}=0.18$

14 and then stabilized. There was a significant interaction between maturity stage and impact energy, with pit depth always higher for $0.0107 \mathrm{~J}$ impact energy compared with $0.00342 \mathrm{~J}$, but dark red fruit showed increased depth compared to red fruit only at the highest impact level. On the other hand 'Sweetheart' showed a gradual increase in pit depth between days 7 and 28, the higher the impact level the greater pit depth and maturity stage did not affect this parameter. On average over time, there was a 1.8 fold in pit depth for both cultivars.

Pit volume indicated for both cultivars a greater volume of damage at higher impact level and longer storage time while maturity stage showed no effect on this parameter. On average pit volume increased in 'Regina' from 0.35 to $0.78 \mathrm{~mm}^{3}$ on days 7 to 28 , while 'Sweetheart' registered 0.56 and $1.57 \mathrm{~mm}^{3}$ on these same days indicating a 2.2 and 2.8 fold overtime (Figure 6). Pit volume could not be related to fruit firmness in 'Regina' $(\mathrm{r}=-0.03)$ while a positive relationship was observed for 'Sweetheart' ( $\mathrm{r}=0.49, \mathrm{P} \leq 0.05)$.

The coefficient of variation (CV) observed for the induced pitting method presented showed repeatability of results independent of the impact energy applied or the variety studied (Figures 4, 5 and 6). Among induced pitting parameters studied, pit diameter showed lower CV than pit depth, what is in accordance with results that showed less evolution of pit diameter as compared to pit depth over time. CV of pit volume was highest of all as expected since
Figure 5. Development of induced pitting average depth for 'Regina' (A) and 'Sweetheart' (B) cherries during storage.
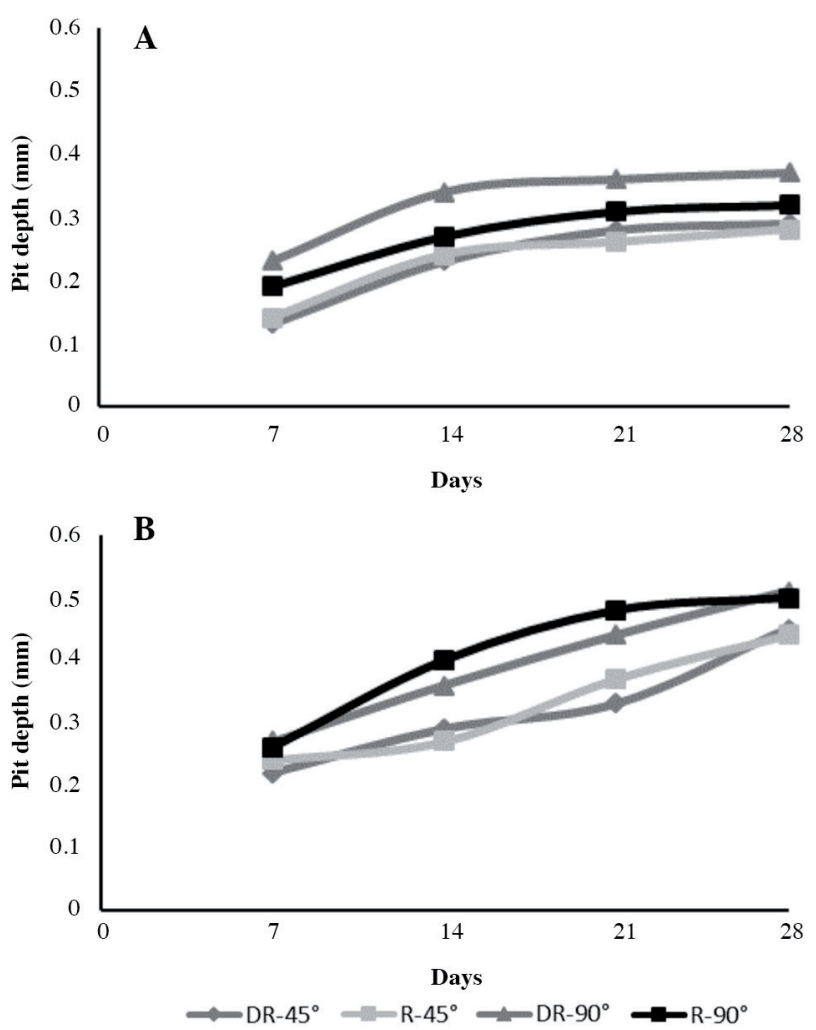

DR: Dark red, R: red, $45^{\circ}: 0.00342 \mathrm{~J}, 90^{\circ}: 0.0107 \mathrm{~J}$.

$\mathrm{CV}$ 'Regina' $45^{\circ}=0.37 ; \mathrm{CV}$ 'Regina' $90^{\circ}=0.39$

$\mathrm{CV}$ 'Sweetheart' $45^{\circ}=0.37$; CV 'Sweetheart' $90^{\circ}=0.36$

this parameter is calculated based on pit diameter and depth (Equation 7).

Cultivar comparison of pitting occurring naturally on cherries during harvest and storage indicated for the red stage fruit, significant differences only in the light damage category, where 'Sweetheart' had a higher proportion of fruit compared to 'Regina'. The dark red fruit showed a higher proportion of sound fruit for 'Regina' compared to 'Sweetheart', with no significant differences between cultivars for the other categories (Figure 7).

\section{DISCUSSION}

The induced pitting method described with the device presented, allowed applying a controlled mechanical injury on the fruit of known impact energy, proving useful for pitting susceptibility determination among cultivars. In earlier work, fruit was dropped from a known distance onto a surface to induce injury (Crisosto et al., 1993) or a known weight was dropped onto the fruit (Toivonen et al., 2004; Kappel and Toivonen, 2005).

Fruit composition parameters in both cultivars evidenced two fruit maturity stages as indicated by soluble solids, $\mathrm{pH}$ and acidity fruit levels. During storage soluble solids content did not change but titratable acidity decreased considerably 
Figure 6. Development of induced pitting average volume for 'Regina' (A) and 'Sweetheart' (B) cherries during storage.
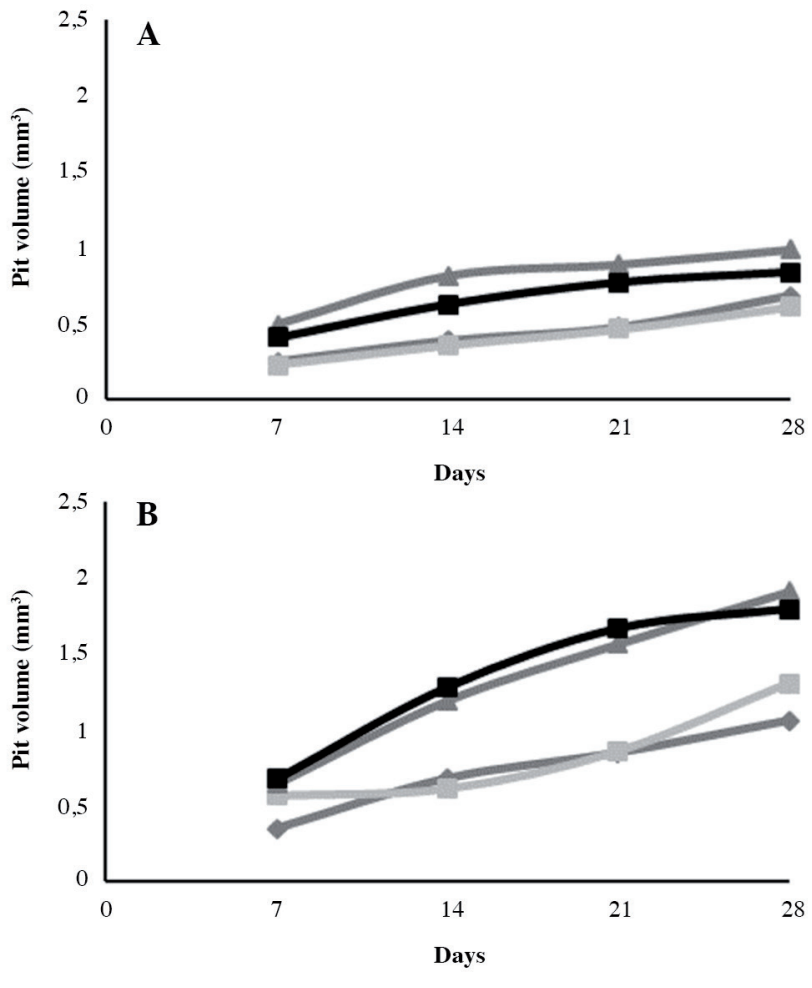

$\because \mathrm{DR}-45^{\circ} \rightarrow \mathrm{R}-45^{\circ} \longrightarrow \mathrm{DR}-90^{\circ} \rightarrow \mathrm{R}-90^{\circ}$

DR: Dark red, R: red, $45^{\circ}: 0.00342 \mathrm{~J}, 90^{\circ}: 0.0107 \mathrm{~J}$.

$\mathrm{CV}$ 'Regina' $45^{\circ}=0.61 ; \mathrm{CV}$ 'Regina' $90^{\circ}=0.62$

$\mathrm{CV}$ 'Sweetheart' $45^{\circ}=0.61 ; \mathrm{CV}$ 'Sweetheart' $90^{\circ}=0.53$

by the end of storage, attributed to fruit respiration. Fruit behavior was in agreement with behavior of other cherry cultivars during cold storage (Wang and Long, 2014; Wang et al., 2015). A controlled single impact applied on the fruit was not enough to affect fruit physicochemical parameters, in contrast to reports where bruising leads to changes in sugar-acid balance (Alique et al., 2005).

Texture is one of the most important quality attributes in cherries that affects consumer acceptance (Ross et al., 2009; Hampson et al., 2014). Fruit firmness decreased during storage of both cultivars as indicated by a higher deformation capacity of the tissue with time, attributed to a loss in cell turgidity (Wang and Vestrheim, 2002). Red stage fruit indicated for both cultivars higher firmness values. Barrett and Gonzalez (1994) observed that in advanced maturity stage firmness loss occurs due to higher enzymatic hydrolysis of cell wall pectins in the mesocarp tissue. More recently, Wei et al. (2011) observed inhibition of cherry fruit softening during cold storage of 1-MCP treated fruit what was explained by an inhibition of cell wall changes in parallel with a decrease in activity of cell wall degrading enzymes polygalacturonase, pectin methylesterase, and $\beta$-galactosidase. Cell wall composition (Salato et al., 2013) and fruit Ca status (Wang et al., 2014) are fruit firmness determinants that have been related to pitting
Figure 7. Pitting damage according to the commercial scale for 'Sweetheart' and 'Regina' cherries at red (A) and dark red stage (B) during harvest and storage.
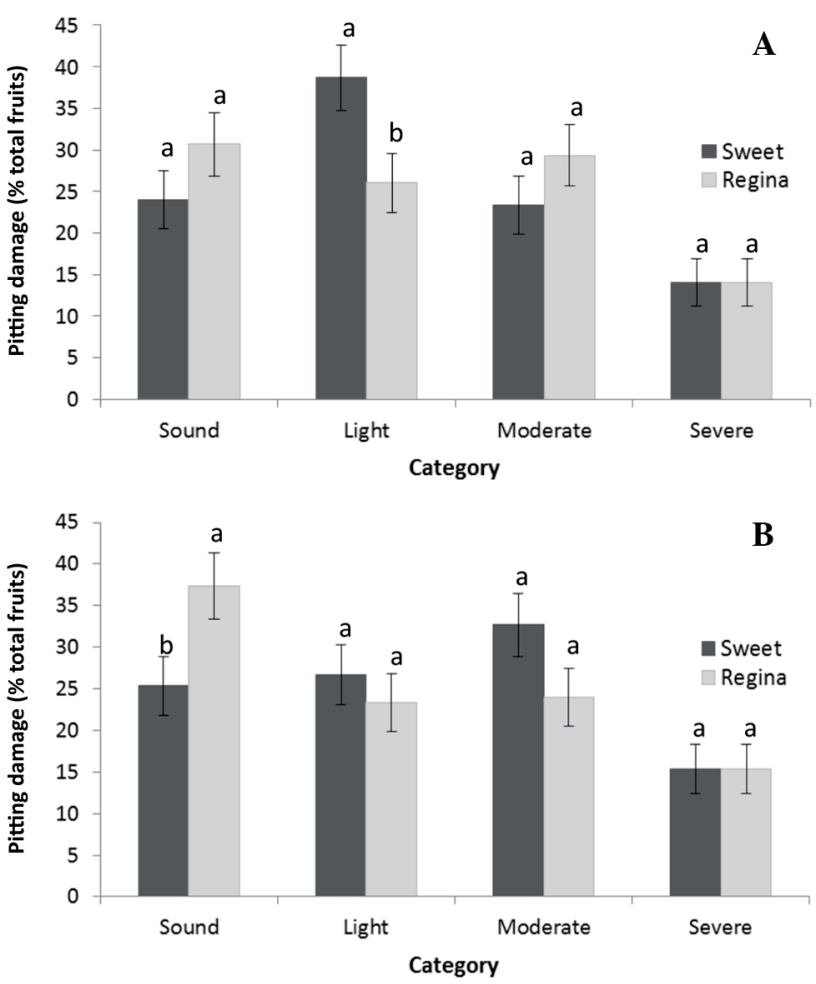

Different letters indicate significant differences within a same category ( $\mathrm{P}$ $\leq 0.05)$.

Vertical bars correspond to standard error.

susceptibility. Einhorn et al. (2013) indicated that growth regulator gibberellic acid applications increased cherry firmness and reduced pitting. Nevertheless we could not observe a relationship between fruit firmness and induced pitting in 'Regina' $(\mathrm{r}=-0.03)$ while a positive relationship was observed in 'Sweetheart' $(\mathrm{r}=0.49 ; \mathrm{P} \leq 0.05)$, where firmer fruit of greater tissue stiffness indicated by a lower deformation capacity, showed greater mechanical damage. For this cultivar, a less elastic skin and pulp may explain greater damage. Brüggenwirth and Knoche (2016b) observed different skin mechanical properties among cherry cultivars of contrasting susceptibility to skin cracking and suggested these differences were due to cell wall physical and possibly chemical properties. In previous studies comparing cultivars (Toivonen et al., 2004; Kappel et al., 2006) pitting injury relationship to fruit firmness has not yet been elucidated coincident with present results, indicating further studies needed to address this important aspect to fruit quality.

Weight loss increased with storage time in both cultivars. Wang and Vestrheim (2002) observed that fruit harvested in advanced maturity stage had higher respiration rate and weight loss, evidencing more pitting damage. Weight loss in storage was a good predictor of pitting susceptibility in 'Bing', but not in 'Lapins' or 'Sweetheart' where there was 
no trend between these parameters (Toivonen et al., 2004). In this study, results show that maturity stage influenced weight loss only in 'Sweetheart', but no differences in pitting were observed among maturity stages in this cultivar. Differences in pitting damage among cultivars cannot be related to fruit weight loss since both cultivars expressed similar ranges during storage. Wang et al. (2015) indicated that the use of modified atmosphere packaging (MAP) liners greatly reduced accumulative weight loss to less than $1 \%$ during cold storage, but no differences were observed among MAP treatments in pitting incidence for late 'Lapins' and 'Skeena' after 6 wk at $0{ }^{\circ} \mathrm{C}$.

The imprint method used could not determine surface pitting injury on day 0. Wade and Bain (1980) described the damage as a collapse of epidermal and hypodermal cells in the void area caused by the necrotic lesion causing the development of the pit, which becomes noticeable as time passes. Apparently, healthy sound fruit could be damaged therefore not manifesting this quality defect until later, which would counter the selection process prior to marketing (Candan et al., 2014). The development of the pitting injury in this study indicated for both cultivars that the advance of the damage in depth was much greater than its diameter as observed by Toivonen et al. (2004). In general, scales used to quantify the incidence of pitting during commercial quality control only consider diameter of the damage. Pitting injury by the end of storage time evaluated was twice in volume for 'Sweetheart' as compared to 'Regina' at the same impact energy levels that infers less tolerance to mechanical impact in the first cultivar. Results of pitting damage occurring naturally during harvest and storage confirmed those obtained with respect to induced pitting. Findings among cultivars should be taken into consideration as fruit is destined to markets of late harvest. Fruit trade with long distance markets involves intensive harvest and postharvest practices, requiring fruit highly tolerant to mechanical injury (Zoffoli et al., 2008). Information on cultivar pitting susceptibility is therefore critical as it allows for preventive measurements that help diminish economical losses.

\section{CONCLUSIONS}

The induced pitting device presented proved to be a reliable method to generate a controlled mechanical injury of known impact energy applied, useful for postharvest pitting studies. Fruit maturity stages of harvested fruit indicated no influence of this factor on damage development. The higher the impact energy applied and the longer the time in storage the greater the damage observed. 'Sweetheart' had a higher pitting incidence compared to 'Regina', in the development of both induced and commercial pitting damage. Fruit firmness may be related to pitting susceptibility in 'Sweetheart' but not in 'Regina'.

\section{ACKNOWLEDGEMENTS}

This work was financially sponsored by the FONDECYT project $\mathrm{N}^{\circ} 11110231$, 'How do fruit turgor and physiological parameters affect pitting susceptibility during postharvest storage in sweet cherry?'

\section{REFERENCES}

Alique, R., J.P. Zamorano, M.A. Martínez, and J. Alonso. 2005. Effect of heat and cold treatments on respiratory metabolism and shelf-life of sweet cherry, type picota cv. Ambrunés. Postharvest Biology and Technology 35:153-165.

Barrett, D.M., and C. Gonzalez. 1994. Activity of softening enzymes during cherry maturation. Journal of Food Science 59:574-577.

Brüggenwirth, M., and M. Knoche. 2016a. Factors affecting mechanical properties of the skin of sweet cherry fruit. Journal of the American Society of Horticultural Science 141(1):45-53.

Brüggenwirth, M., and M. Knoche. 2016b. Mechanical properties of skins of sweet cherry fruit of differing susceptibilities to cracking. Journal of the American Society of Horticultural Science 141(2): 162-168

Candan, A.P., M.D. Raffo, G. Calvo, and T. Gomila. 2014. Study of the main points of impact during cherry handling and factors affecting pitting sensitivity. Acta Horticulturae 1020:137-141.

Clayton, M., W.V. Biasi, I.T. Agar, S.M. Southwick, and E.J. Mitcham. 2006. Sensory quality of 'Bing' sweet cherries following preharvest treatment with hydrogen cyanamide, calcium ammonium nitrate, or gibberellic acid. HortScience 41(3):745-748.

Crisosto, C.H., G.M. Crisosto, and P. Metheney. 2003. Consumer acceptance of 'Brooks' and 'Bing' cherries is mainly dependent on fruit SSC and visual skin color. Postharvest Biology and Technology 28(1):159-167.

Crisosto, C.H., D. Garner, J. Doyle, and K.R. Day. 1993. Relationship between fruit respiration, bruising susceptibility, and temperature in sweet cherries. HortScience 28(2):132-135.

Einhorn, T.C., Y. Wang, and J. Turner. 2013. Sweet cherry fruit firmness and postharvest quality of late-maturing cultivars are improved with low-rate, single applications of gibberellic acid. HortScience 48(8):1010-1017.

Facteau, T.J., and K.E. Rowe. 1979. Factors associated with surface Pitting of sweet cherry. Journal of the American Society for Horticultural Science 104(5):706-710.

Hampson, C.R., K. Stanich, D.L. McKenzie, L. Herbert, R. $\mathrm{Lu}, \mathrm{J}$. Li, et al. 2014. Determining the optimum firmness for sweet cherries using Just-About-Right sensory methodology. Postharvest Biology and Technology 91:104-111.

Kappel, K.P., and P. Toivonen. 2005. Resistance of advanced sweet cherry selections and cultivars to fruit surface pitting. Acta Horticulturae 667:515-521.

Kappel, K., P. Toivonen, S. Stan, and D.L. McKenzie. 2006. Resistance of sweet cherry cultivars to fruit surface pitting. Canadian Journal of Plant Science 86(4):1197-1202.

Kupferman, E., and P. Sanderson. 2005. Temperature management and modified atmosphere packing to preserve sweet cherry fruit quality. Acta Horticulturae 667:523-528.

Lidster, P.D., K. Muller, and M.A. Tung. 1980. Effects of maturity on fruit composition and susceptibility to surface damage in sweet cherries. Canadian Journal of Plant Science 60(3):865-871. 
Lidster, P.D., and M.A. Tung. 1980. Effects of fruit temperatures at time of impact damage and subsequent storage temperature and duration on the development of surface disorders in sweet cherries. Canadian Journal of Plant Science 60(2):555-559.

Mitcham, E.J., M. Clayton, and W.V. Biasi. 1998. Comparison of devices for measuring cherry fruit firmness. HortScience 33(4):723-727.

Porritt, S.W., L.E. Lopatecki, and M. Meheriuk. 1971. Surface pitting - a storage disorder of sweet cherries. Canadian Journal of Plant Science 51(5):409-414.

Ross, C.F., M.A. Chauvin, and M. Whiting. 2009. Firmness evaluation of sweet cherries by a trained and consumer sensory panel. Journal of Texture Studies 40(5):554-570.

Salato, G.S., N.M.A. Ponce, M.D. Raffo, A.R. Vicente, and C.A. Stortz. 2013. Developmental changes in cell wall polysaccharides from sweet cherry (Prunus avium L.) cultivars with contrasting firmness. Postharvest Biology and Technology 84:66-73.

Toivonen, P.M.A., C. Hampson, S. Stan, D.-L. McKenzie, and R. Hocking. 2007. Factors affecting severity of bruises and degree of apparent bruise recover in a yellow-skinned apple. Postharvest Biology and Technology 45(2):276-280.

Toivonen, P.M.A., F. Kappel, S. Stan, D.-L. Mckenzie, and R. Hocking. 2004. Firmness, respiration, and weight loss of 'Bing', 'Lapins' and 'Sweetheart' cherries in relation to fruit maturity and susceptibility to surface pitting. HortScience 39(5):1066-1069.

Torrealba, C. 2005. Herramientas de segregación en cerezas (Prunus avium L.) según susceptibilidad a pitting. 85 p. Tesis Magister. Pontificia Universidad Católica de Chile, Facultad de Agronomía e Ingeniería Forestal, Santiago, Chile.
Wade, N.L., and J.M. Bain. 1980. Physiological and anatomical studies of surface pitting of sweet cherry fruit in relation to bruising, chemical treatments and storage conditions. Journal of Horticultural Science 55(4):375-384.

Wang, Y., J. Bai, and L.E. Long. 2015. Quality and physiological responses of two late-season sweet cherry cultivars 'Lapins' and 'Skeena' to modified atmosphere packaging (MAP) during simulated long distance ocean shipping. Postharvest Biology and Technology 110:1-8.

Wang, Y., and L.E. Long. 2014. Respiration and quality responses of sweet cherry to different atmospheres during cold storage and shipping. Postharvest Biology and Technology 92:62-69.

Wang, L., and S. Vestrheim. 2002. Controlled atmosphere storage of sour cherry (Prunus cerasus L.) Acta Agriculturae Scandinavica Section B Soil and Plant Science 52(4):143-146.

Wang, Y., X. Xie, and L.E. Long. 2014. The effect of postharvest calcium application in hydro-cooling water on tissue calcium content, biochemical changes, and quality attributes of sweet cherry. Food Chemistry 160:22-30.

Wei, J., X. Qi, J. Guan, and X. Zhu. 2011. Effect of cold storage and 1-MCP treatment on postharvest changes of fruit quality and cell wall metabolism in sweet cherry. Journal of Food, Agriculture \& Environment 9(3-4):118-122.

Zoffoli, J.P. 2012. Nuove tecnologie post-raccolta per mantenere la qualità del prodotto. Rivista di Frutticoltura e Ortofloricoltura 74(4):44-46.

Zoffoli, J.P., S. Muñoz, L. Valenzuela, M. Reyes, and F. Barros. 2008. Manipulation of 'Van' sweet cherry crop load influences fruit quality and susceptibility to impact bruising. Acta Horticulturae (795):877-891 